Slamet Mardiyanto Rahayu, Wiryanto, dan Sunarto. (2018). Keanekaragaman Kepiting Biola di Kawasan Mangrove Kabupaten Purworejo, Jawa Tengah. Vol. 4 (1) Pp. 53-63. Doi: https://doi.org/10.23917/bioeksperimen.v4i1.3136

\title{
Keanekaragaman Kepiting Biola di Kawasan Mangrove Kabupaten Purworejo, Jawa Tengah
}

\author{
Slamet Mardiyanto Rahayu ${ }^{1) *}$, Wiryanto ${ }^{2)}$, dan Sunarto ${ }^{2)}$ \\ ${ }^{1)}$ Mahasiswa Magister Biosain, Universitas Sebelas Maret \\ ${ }^{2}$ Staf Pengajar Program Studi Magister Biosain, Universitas Sebelas Maret \\ *Email: slamet.mardiyantorahayu84@gmail.com
}

\begin{abstract}
Abstrak
Mangrove merupakan ekosistem yang khas dan memiliki fungsi penting secara ekologi, sosial-ekonomi, dan pendidikan. Luas kawasan mangrove di Kabupaten Purworejo semakin berkurang akibat adanya penebangan, permukiman, tambak, dan pertanian. Berkurangnya tegakan mangrove akan mempengaruhi keberadaan berbagai fauna yang berasosiasi dengannya. Oleh karena itu dilakukan pada bulan Agustus-September 2016 untuk mengetahui keanekaragaman kepiting biola di kawasan mangrove Kabupaten Purworejo, Jawa Tengah. Ada tiga stasiun, yaitu mangrove lebat (Desa Gedangan), mangrove sedang (Desa Jatikontal), dan mangrove jarang (Desa Ngentak). Dari penelitian didapatkan 7 jenis kepiting biola, yaitu Uca annulipes, U.crassipes, U.paradussumieri, U.rosea, U.tetragonon, U.vocans, dan U.vomeris. Indeks keanekaragaman kepiting biola di kawasan mangrove Kabupaten Purworejo, Jawa Tengah pada stasiun $1(1,67)$ dan stasiun $2(1,90)$ tergolong sedang. Adapun indeks keanekaragaman kepiting biola di stasiun $3(0,64)$ tergolong rendah. Kondisi lingkungan di seluruh stasiun relatif baik untuk kehidupan mangrove dan kepiting biola, yaitu suhu 26-30 $\mathrm{C}$, pH 6-8, oksigen terlarut 3,5-6,6 mg/L, salinitas 3-9 ppt, dan substrat lumpur berpasir. Vegetasi mangrove pada stasiun I adalah Rhizophora mucronata, Nypa fruticans, Sonneratia alba, dan Hibiscus tiliaceus. Vegetasi mangrove pada stasiun II adalah Sonneratia caseolaris, Rhizophora stylosa, N.fruticans, H.tiliaceus, dan Morinda citrifolia. Vegetasi mangrove pada stasiun III adalah S.alba, S.caseolaris, N.fruticans, dan R.mucronata. Kerapatan vegetasi mangrove berkaitan dengan kelimpahan jenis (kepadatan) kepiting biola.
\end{abstract}

Kata Kunci: kepiting biola, mangrove, Purworejo, keanekaragaman

\section{PENDAHULUAN}

Hutan mangrove dapat didefinisikan sebagai suatu tipe hutan yang tumbuh di daerah pasang surut, terutama di pantai yang terlindung, laguna, muara sungai yang tergenang pasang dan bebas dari genangan pada saat surut yang komunitas tumbuhannya bertoleransi terhadap garam. Selanjutnya ekosistem mangrove merupakan suatu sistem yang terdiri atas organisme (tumbuhan dan hewan) yang berinteraksi dengan faktor lingkungannya di dalam suatu habitat mangrove (Onrizal, 2008).

Purworejo merupakan salah satu kabupaten yang berada di bagian selatan Provinsi Jawa Tengah. Kawasan mangrove di Kabupaten Purworejo terdapat di Kecamatan Purwodadi, Ngombol, dan Grabag (Pemerintah Kabupaten Purworejo, 2011). Kawasan mangrove di Kabupaten Purworejo semakin berkurang akibat adanya penebangan pohon, konversi menjadi area tambak budidaya ikan maupun udang, permukiman, dan area pertanian (Badan Perencanaan Pembangunan Daerah Kabupaten Purworejo, 2016). Penebangan dan berbagai bentuk konversi lahan mangrove di Kabupaten Purworejo telah menyebabkan terjadinya degradasi kawasan mangrove berupa berkurangnya tegakan mangrove yang signifikan. Berkurangnya tegakan mangrove mempengaruhi perubahan faktor fisika kimia lingkungan mangrove sehingga mengganggu kehidupan fauna yang berasosiasi dengan vegetasi mangrove, misalnya kepiting biola (genus $U c a$ ).

Uca merupakan salah satu jenis kepiting yang memiliki habitat di daerah intertidal, terutama di sekitar hutan mangrove dan pantai berpasir. Beberapa jenis Uca ditemukan dalam jumlah yang melimpah dalam habitat mangrove (Crane, 1975). Jumlah kepiting biola yang ada di dunia mencapai 97 jenis. Dari jumlah tersebut, 19 jenis sudah teridentifikasi terdapat di Indonesia. Kepiting biola memiliki karakter yang unik, memiliki dimorfisme 
seksual pada ukuran capitnya di mana ukuran salah satu capit jantan dewasa yang sangat besar dan bisa mencapai dua kali ukuran karapasnya (ukuran karapas jantan dewasa dapat mencapai $30 \mathrm{~mm}$ ). Salah satu fungsi capit yang besar yaitu untuk menarik perhatian betinanya dan menakuti musuhnya. Capit yang kecil berfungsi untuk makan (Rosenberg, 2001). Kepiting biola berperan dalam menjaga keseimbangan rantai makanan dan siklus nitrogen dalam ekosistem mangrove. Kepiting biola berperan sebagai detritivor di ekosistem mangrove (Wulandari, 2013).

Kepiting biola ( $U_{c a}$ spp.) termasuk fauna mangrove yang menggantungkan hidupnya pada mangrove. Kepiting biola keluar dan turun mencari makan ketika surut pada substrat mangrove. Uca spp. merupakan pemakan detritus (detrivor) yang membantu dekomposisi pada mangrove sehingga keberadaannya sangat penting dalam rantai makanan ekosistem mangrove. Kepiting biola juga menjadikan mangrove sebagai habitat tempat berpijah dan tempat mengasuh untuk melangsungkan siklus hidupnya agar tetap lestari (Hamidah dkk., 2014).

Degradasi kawasan mangrove menyebabkan perubahankomposisidan strukturvegetasi mangrove (Odum, 1993), merusak keseimbangan ekosistem dan habitat (faktor fisika kimia lingkungan) serta kepunahan spesies ikan dan biota laut yang hidup di dalamnya, serta abrasi pantai (Polidoro et al., 2010). Degradasi kawasan mangrove di Kabupaten Purworejo yang terjadi secara terus menerus dapat menyebabkan penurunan keanekaragaman vegetasi dan kepiting biola yang berasosiasi dengan mangrove. Sampai saat ini belum ada data tentang keanekaragaman kepiting biola di kawasan mangrove Kabupaten Purworejo, Jawa Tengah.

Sehubungan dengan permasalahan tersebut, maka perlu dilakukan penelitian untuk mengetahui keanekaragaman kepiting biola di kawasan mangrove Kabupaten Purworejo, Jawa Tengah

\section{Metode}

Penelitian dilakukan pada bulan AgustusSeptember 2016. Penentuan lokasi dilakukan dengan metode purposive sampling. Stasiun I (Desa Gedangan dengan kondisi mangrove lebat) berada pada posisi $07^{\circ} 50^{\prime} 16,0^{\prime \prime} S-110^{\circ} 00^{\prime} 33,2^{\prime \prime} E$. Stasiun II (Desa Jatikontal dengan kondisi mangrove sedang) berada pada posisi $07^{\circ} 52^{\prime} 54,3$ "S-109'59'31,4”E. Stasiun III (Desa Ngentak dengan kondisi mangrove jarang) berada pada posisi $07^{\circ} 52^{\prime} 16,5^{\prime \prime}$ S- $109^{\circ} 58^{\prime} 20,4$ 'E.

Alat dan bahan yang digunakan dalam penelitian ini adalah patok kayu, meteran/rol meter, GPS, buku Pengenalan Mangrove Indonesia (Noor dkk., 2012), buku A Guide to Mangrove of Singapore (Ng and Sivasothi, 2001), $\mathrm{pH}$ meter, termometer, hand refractometer, DO meter, kamera digital, alat tulis serta, laptop.

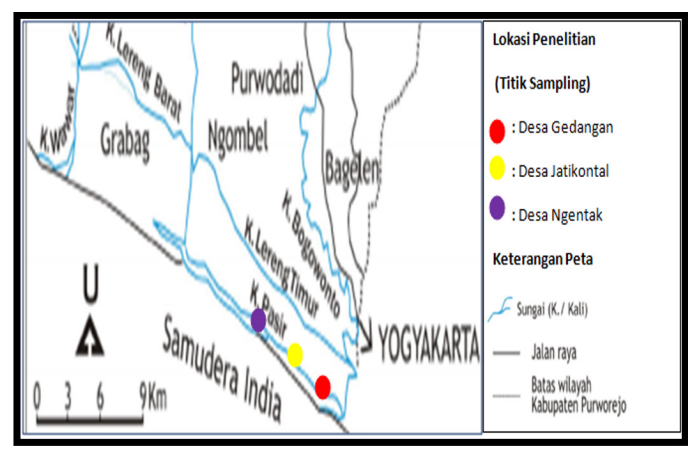

Gambar 1 Lokasi stasiun penelitian di kawasan mangrove Kabupaten Purworejo, Jawa Tengah

\section{Pengambilan Data}

Pengambilan data kepiting biola dilakukan pada setiap stasiun dengan memasang transek sepanjang $500 \mathrm{~m}$ terdiri dari 10 plot ukuran $1 \mathrm{x} 1 \mathrm{~m}$. Sampel kepiting biola difiksasi dengan alkohol $40 \%$ dan diawetkan pada alkohol 70\% (Suprayogi dkk., 2014). Hasil awetan diidentifikasi buku $A$ Guide to Mangrove of Singapore ( $\mathrm{Ng}$ and Sivasothi, 2001). Pengambilan data faktor lingkungan dilakukan secara insitu meliputi suhu air, $\mathrm{pH}$, oksigen terlarut, salinitas, dan substrat. Pengambilan data vegetasi mangrove dilakukan pada 10 plot dengan masing-masing plot terdiri dari 3 petak ukuran 10x10m (untuk pohon), 5x5m (untuk pancang), dan $2 \times 2 m$ (untuk semai dan tumbuhan bawah). Vegetasi mangrove diidentifikasi berdasarkan buku Pengenalan Mangrove Indonesia (Noor dkk., 2012).

\section{Pengukuran Data}

a. Kelimpahan Jenis (Kepadatan) 


$$
\mathrm{K}=\frac{\text { jumlah individu }}{\text { luas seluruh petak contoh }}
$$

b. Indeks Keanekaragaman (H')

$$
\text { Indeks keanekaragaman }
$$

menggunakan rumus indeks keanekaragaman

Shannon-Wienner dalam Soegianto (1994), yaitu:

$$
H^{\prime}=-\sum \frac{n i}{N} \ln \frac{n i}{N}
$$

Keterangan:

\begin{tabular}{|c|c|c|c|c|c|c|c|c|c|c|c|}
\hline \multirow[t]{2}{*}{ No } & \multirow[t]{2}{*}{ Jenis } & \multicolumn{4}{|c|}{ Jumlah Individu } & \multicolumn{3}{|c|}{$\begin{array}{c}\text { Kelimpahan Jenis (ind/ } \\
\mathbf{m}^{2} \text { ) }\end{array}$} & \multicolumn{3}{|c|}{$\begin{array}{c}\text { Indeks } \\
\text { Keanekaragaman Jenis }\end{array}$} \\
\hline & & St 1 & St 2 & St 3 & Total & St 1 & St 2 & St 3 & St 1 & St 2 & St 3 \\
\hline 1 & Uca annulipes & 160 & 25 & 8 & 193 & 16,0 & 2,5 & 0,8 & \multirow{8}{*}{1,67} & \multirow{8}{*}{1,90} & \multirow{8}{*}{0,64} \\
\hline 2 & U.vomeris & 120 & 23 & 0 & 143 & 12,0 & 2,3 & 0 & & & \\
\hline 3 & U.vocans & 51 & 18 & 0 & 69 & 5,1 & 1,8 & 0 & & & \\
\hline 4 & U.rosea & 33 & 13 & 16 & 62 & 3,3 & 1,3 & 1,6 & & & \\
\hline 5 & U.tetragonon & 25 & 22 & 0 & 47 & 2,5 & 2,2 & 0 & & & \\
\hline 6 & U.crassipes & 20 & 10 & 0 & 30 & 2,0 & 1,0 & 0 & & & \\
\hline \multirow[t]{2}{*}{7} & U.paradussumieri & 40 & 13 & 0 & 53 & 4,0 & 1,3 & 0 & & & \\
\hline & Total & 449 & 124 & 24 & 597 & & & & & & \\
\hline
\end{tabular}

U.paradussumieri, U.rosea, U.tetragonon, U.vocans, dan U.vomeris (Tabel 1).

Tabel 1 Jenis kepiting biola di kawasan mangrove Kabupaten Purworejo, Jawa Tengah

Kepiting biola merupakan jenis kepiting dari salah satu kelompok ordo Decapoda dan termasuk ke dalam famili Ocypodidae. Ocypodidae adalah salah satu jenis kepiting yang memiliki habitat
$\mathrm{H}^{\prime}=$ indeks diversitas (keanekaragaman) Shannon-Wiener

ni $=$ jumlah setiap jenis ke-i

$\mathrm{N}=$ jumlah total (keseluruhan) individu

\section{Hasil dan Pembahasan}

\section{Kelimpahan dan Keanekaragaman Jenis Kepiting Biola}

Hasil penelitian didapatkan 7 jenis kepiting biola, yaitu Uca annulipes, U.crassipes, di daerah pasang surut (Murniati, 2009). Jenis kepiting biola yang ditemukan di setiap stasiun tidak sama (Gambar 2). Pada stasiun 1 dan stasiun 2 ditemukan 7 jenis. Adapun pada stasiun 3 hanya ditemukan 2 jenis kepiting biola.

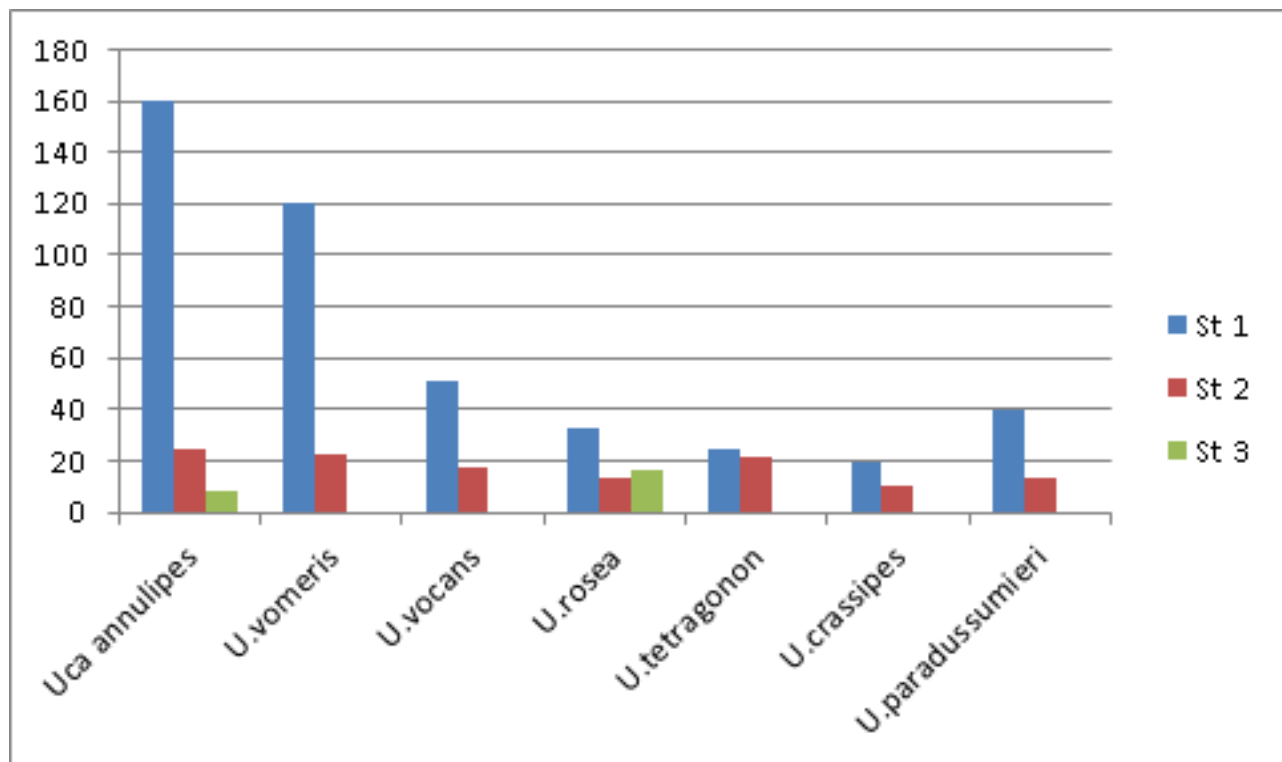

Gambar 2 Jumlah individu jenis kepiting biola di stasiun penelitian 
Berdasarkan penelitian dapat diketahui bahwa jenis kepiting biola yang memiliki kelimpahan jenis tertinggi adalah Uca annulipes. Sedangkan jenis kepiting biola yang memiliki kelimpahan jenis terendah adalah U.crassipes. U.annulipes dan U.rosea dapat ditemukan di seluruh stasiun penelitian. Adapun U.vomeris, U.vocans, U.tetragonon, U.crassipes, dan U.paradussumieri ditemukan pada stasiun 1 dan stasiun 2.

Perbedaan komposisi tersebut disebabkan karena kondisi mangrove (habitat perairan payau) terdapat aliran sungai yang memungkinkan air tawar dan pasang air laut masuk ke lokasi pengamatan sehingga kondisi substrat lebih lunak dan berlumpur.
Nilai keanekaragaman kepiting biola di kawasan mangrove Kabupaten Purworejo, Jawa Tengah pada stasiun 1 dan stasiun 2 tergolong sedang. Adapun nilai keanekaragaman kepiting biola di stasiun 3 tergolong rendah. Indeks keanekaragaman Shannon-Wiener dalam Soegianto (1994) dikelompokkan menjadi tiga, yaitu keanekaragaman tinggi $\left(\mathrm{H}^{\prime}>3\right)$, keanekaragaman sedang $\left(1 \leq \mathrm{H}^{\prime} \leq 3\right)$, dan keanekaragaman rendah $\left(\mathrm{H}^{\prime}<1\right)$. Banyaknya jenis dalam suatu komunitas dan kelimpahan dari tiap jenis akan mempengaruhi keanekaragaman di suatu ekosistem. Keanekaragaman dalam suatu ekosistem akan berkurang jika semakin sedikit jumlah jenis dan adanya variasi jumlah individu dari suatu jenis atau ada beberapa jenis

yang memiliki jumlah individu yang lebih besar.

\section{Deskripsi Jenis Kepiting Biola}

\section{a. Uca annulipes}

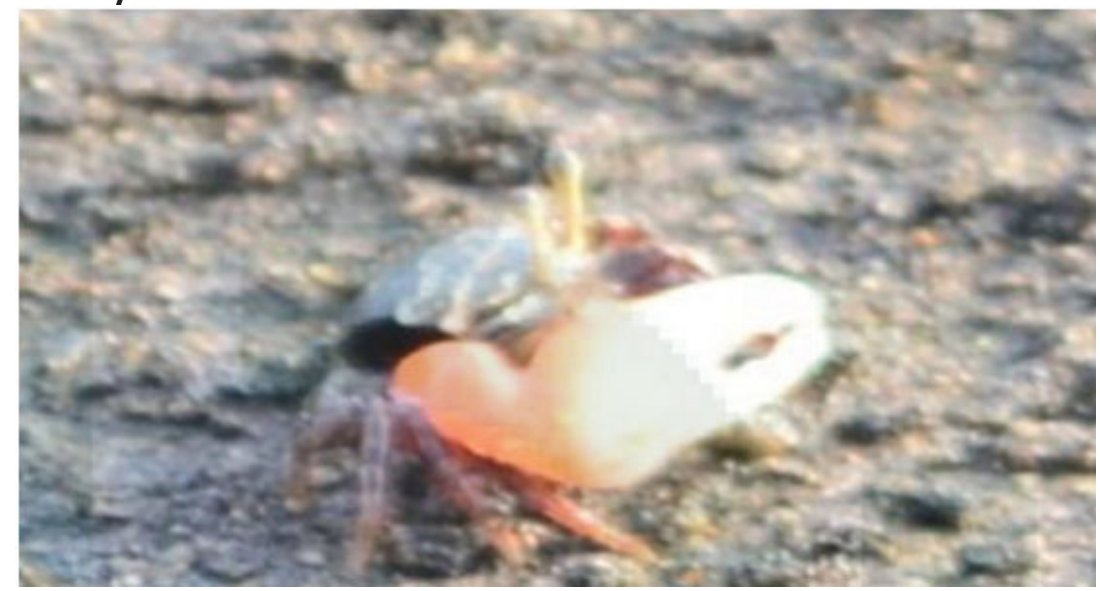

\section{Gambar 3 Uca annulipes}

Berukuran tubuh 25-60 mm, karapas berbentuk trapesium berwarna hitam dengan bintik-bintik putih melintang dekat anterior, orbit tidak tampak, merus, carpus dan manus berwarna merah, halus, dactyl dan pollex berwarna putih. Menurut Wilsey (2000) menyatakan bahwa beberapa jenis $U_{c a}$ dapat hidup bersama di habitat yang sama, tetapi jenis-jenis tersebut biasanya memiliki pola tingkah laku yang berbeda serta memiliki mikrohabitat yang juga berbeda sehingga relung ekologi dari kepiting ini dapat saja terpisah. Distribusinya di Indo-Pasifik Barat meliputi India sampai China selatan, Filipina, Indonesia, dan Malaysia. 


\section{b. Uca vomeris}

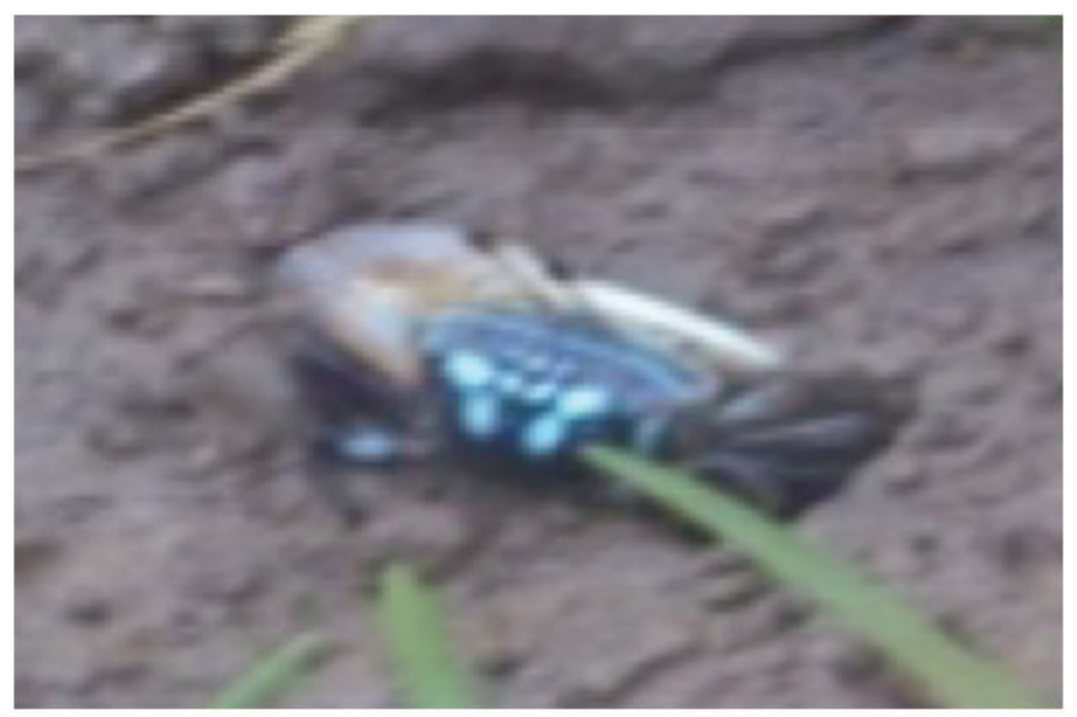

\section{Gambar 4 Uca vomeris}

Tubuhnya memiliki warna yang mencolok. Pada karapas terdapat corak kebiru-biruan. Tangkai mata langsing dengan warna keabu-abuan sampai kecokelatan. Kaki bercapit dengan warna orange, pipih, dan lebar. Habitatnya adalah wilayah pasang surut dengan substrat berpasir. Distribusi di wilayah Indo-Pasifik Barat meliputi Australia, Papua Nugini, Indonesia, dan Melanesia.

\section{c. Uca vocans}

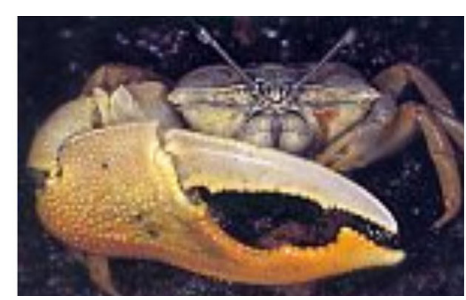

Gambar 5 Uca vocans

Uca vocans berukuran tubuh $30-75 \mathrm{~mm}$, karapas berbentuk trapesium berwarna putih pudar, orbit melekuk tajam, merus dan carpus berwarna putih keabu-abuan, manus berwarna kuning, kasar, dactyl berwarna putih, pollex berwarna kuning. Uca vocans biasanya muncul setelah surut rendah yang berdekatan dengan batas air. Uca vocans ditemukan di daerah yang berlumpur sedikit berpasir dengan kadar air yang tinggi di pinggiran hutan mangrove yang terbuka. Menurut Wilsey (2000) menyatakan kepiting fiddler bersifat semiterestrial serta aktif pada saat air surut. Distribusinya di IndoPasifik Barat meliputi China, Birma, Thailand, Indonesia, dan Malaysia. 


\section{d. Uca rosea}

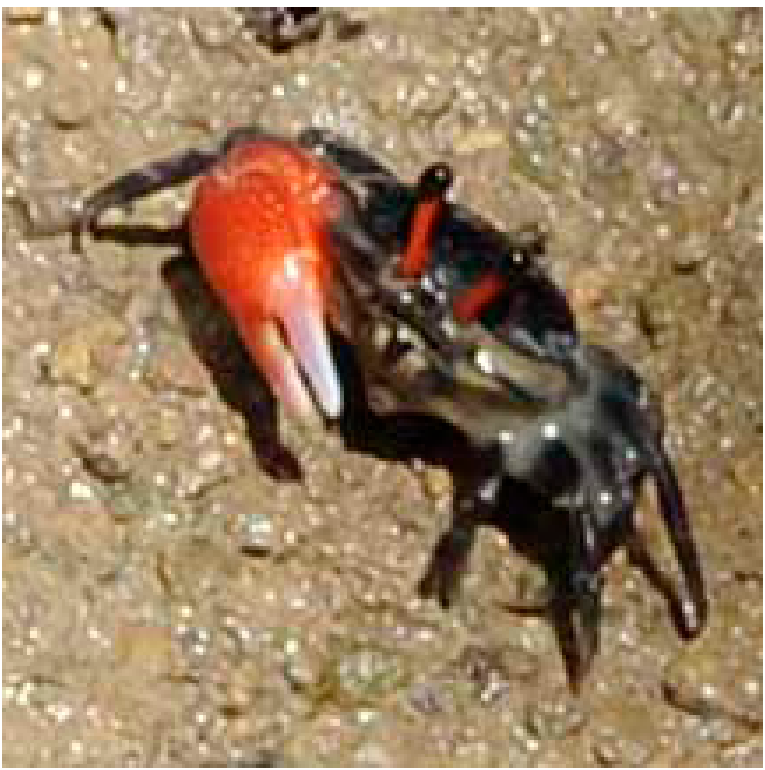

Gambar 6 Uca rosea

Uca rosea hidup pada substrat berlumpur dekat perairan dan vegetasi, ditemukan di sekitar tepi perairan/muara. Memiliki karapas berwarna hitam dan capit besar berwarna merah, karapasnya berbentuk segi empat, dan ujung karapas tumpul, bagian dorsal memanjang pada bagian atas, dan bagian bawah sedikit menyempit, ukuran panjang karapas $10 \mathrm{~mm}$, dan lebar karapas $15 \mathrm{~mm}$. Thorax berwarna hitam, dan abdomen berwarna hitam melengkung, sedikit beruas, capitnya berwarna merah dan di ujung capit berwarna putih, pada permukaan capit bergerigi dan berlekuk, terdapat bintikbintik kasar berwarna hitam, merah, panjang propodus (panjang capit) $15 \mathrm{~mm}$. Tangkai mata dan bintik matanya berwarna hitam, memiliki 4 pasang kaki jalan, dan sepasang capit. Kakinya berwarna hitam, dan capit yang kecil juga berwarna hitam. Menurut Wulandari (2013) Uca rosea jantan memiliki bentuk abdomen yang memanjang dan pada betina lebar dan tumpul. Bagian frontal karapas lebar, ukuran lebar karapas jantan dewasa mencapai $27,5 \mathrm{~mm}$. Hidup pada substrat lumpur dekat sungai dan selalu dekat vegetasi (Murniati, 2010). Distribusinya di Indo-Pasifik Barat meliputi India bagian barat sampai Malaysia dan Indonesia bagian barat.

\section{e. Uca tetragonon}

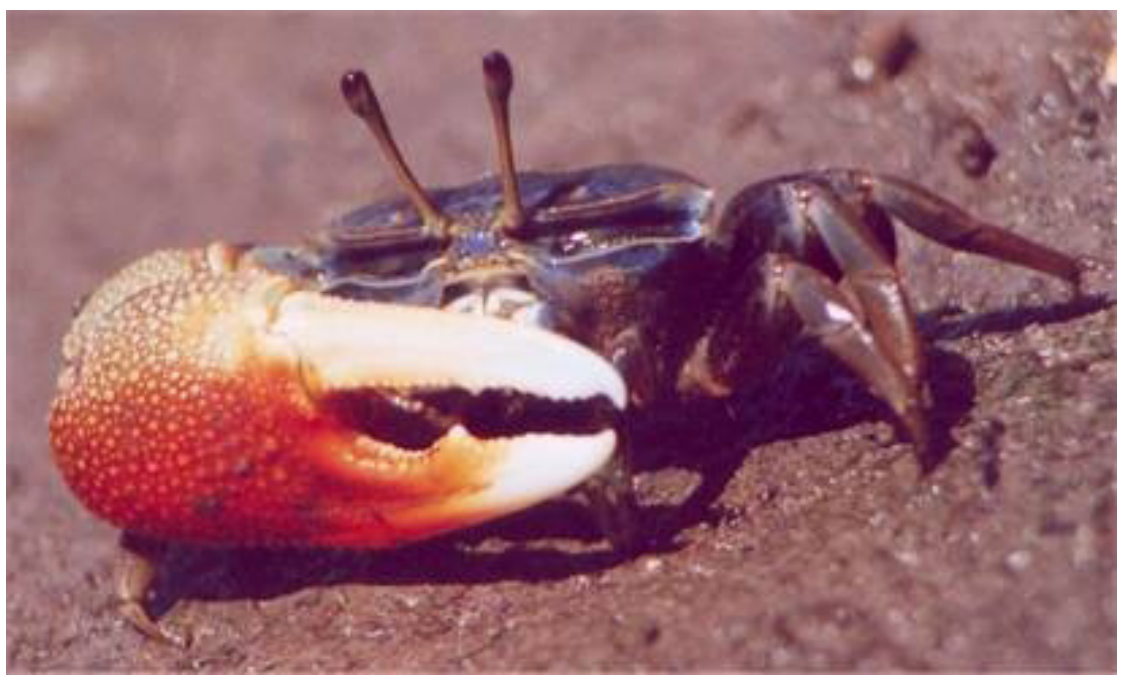

Gambar 7 Uca tetragonon

Uca tetragonon berukuran tubuh 30-75 $\mathrm{mm}$, karapas berbentuk trapesium berwarna hitam dengan bintik-bintik biru melintang, orbit tidak tampak, carpus tungkai belakang berwarna biru di bagian tengah, merus berwarna oranye, carpus tungkai paling depan berwarna oranye pudar, manus bagian dorsal berwarna cokelat keputihan, bagian ventral berwarna oranye, kasar, dactyl dan pollex berwarna putih. Uca tetragonon hanya ditemukan di titik 1-5 yang jauh dari zona intertidal dengan vegetasi Rhizopora sp. yang berdekatan dengan jalan tol dan permukiman warga. Yulianto (2006) menyatakan bahwa 
kepadatan jenis Uca tetragonon dipengaruhi oleh tingginya frekuensi habitat terendam air. Menurut Suzuki dan Hatori (1998) dalam suatu populasi jenis Uca tetragonon betina lebih sering ditemukan daripada yang jantan, sehingga pemanfaatan capit yang besar untuk berkompetisi tidak bisa dilakukan yang menyebabkan individu semakin berkurang (Crane, 1975). Distribusinya di Indo-Pasifik Barat meliputi Afrika Selatan sampai Iran, Madagaskar, Thailand, Malaysia, Australia, Indonesia, Filipina, Papua Nugini, Taiwan, Mikronesia, dan Melanesia.

\section{f. Uca crassipes}

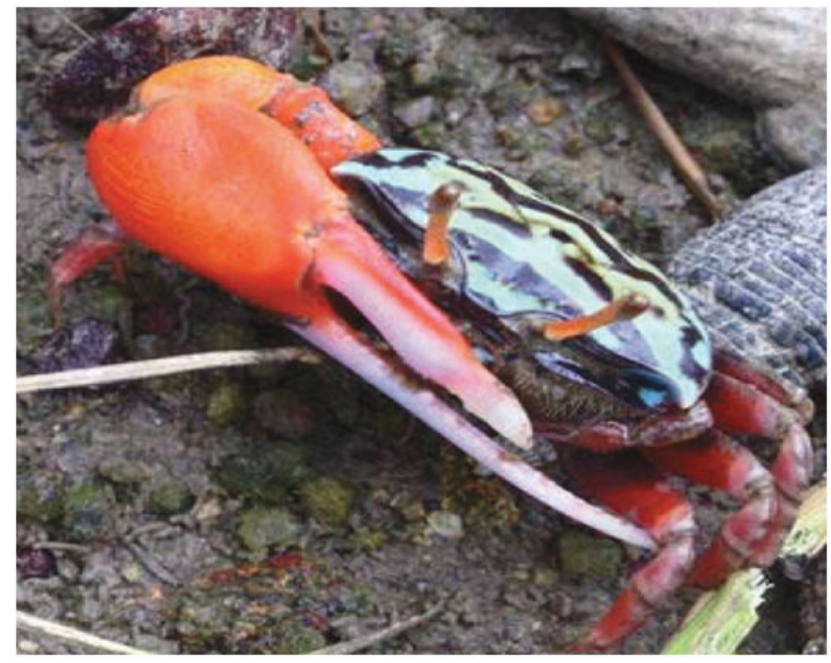

Gambar 8 Uca crassipes

Capit besar berwarna oranye kemerahan dengan bagian bawah capit lebih panjang. Lebar karapas antara 2-2,5 cm dengan warna hijau hitam dan kaki jalan berwarna merah dengan jumlah 4 pasang. Banyak ditemukan pada mangrove bagian hilir sungai dengan tempat yang terbuka. Distribusinya di wilayah Indo-Pasifik Barat meliputi Kaledonia Baru, Australia Timur, Papua Nugini, Filipina, China, dan Kepulauan bagian selatan Jepang.

\section{g. Uca paradussumieri}

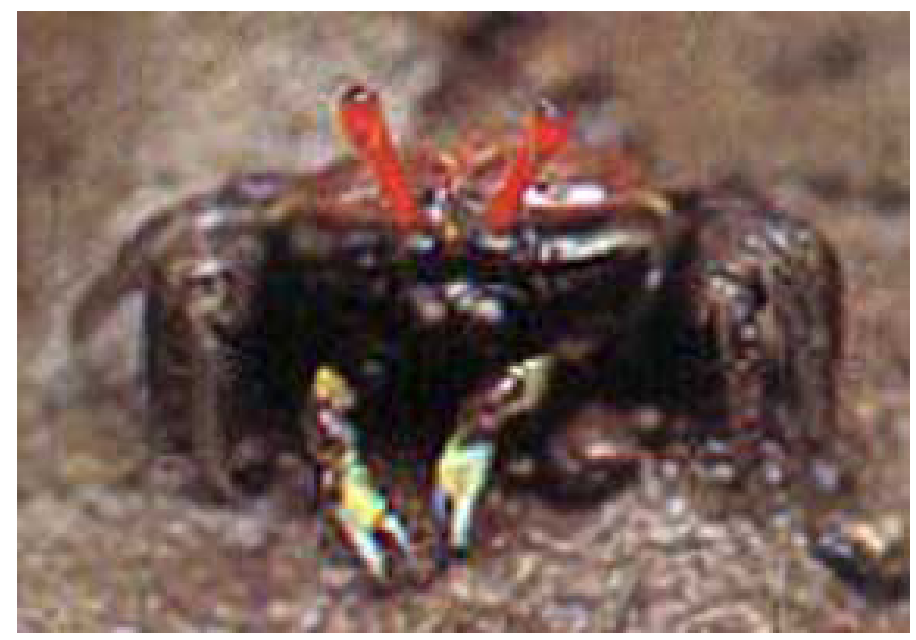

Gambar 9 Uca paradussumieri 
Disebut juga kepiting biola ungu (purple fiddler). Merupakan kepiting mangrove yang obligat (hidupnya tergantung/harus berasosiasi dengan mangrove). Sering ditemukan pada lumpur lunak. Juvenil berkembang dalam lubang (liang). Distribusi (daerah penyebarannya) di Indo-Pasifik Barat meliputi India Timur Laut, Thailand, Indonesia, Malaysia, Kamboja, dan China.

\section{Kondisi Lingkungan Habitat Kepiting Biola}

Faktor fisika kimia lingkungan merupakan parameter lingkungan yang mempengaruhi kehidupan kepiting biola (Uca spp.) pada habitatnya. Faktor fisika kimia lingkungan tersebut meliputi jenis substrat, suhu, $\mathrm{pH}$, oksigen terlarut, dan salinitas air.

Tabel 2 Parameter lingkungan mangrove di Kabupaten Purworejo, Jawa Tengah

\begin{tabular}{cccccc}
\hline Stasiun & $\begin{array}{c}\text { Suhu } \\
\left({ }^{\circ} \mathbf{C}\right)\end{array}$ & $\mathbf{p H}$ & DO (mg/L) & Salinitas (ppt) & Substrat \\
\hline I & $28-30$ & $6,9-8$ & $4-6,5$ & $6-9$ & Lumpur Berpasir \\
II & $27-30$ & $6,5-7,5$ & $4-6,6$ & $5-8$ & Lumpur Berpasir \\
III & $26-29$ & $6-7$ & $3,5-6$ & $3-5$ & Lumpur Berpasir \\
Rata-rata & 28,38 & 6,99 & 4,96 & 5,96 & \\
\hline
\end{tabular}

Substrat merupakan faktor lingkungan yang terpenting bagi kehidupan $U c a$ spp., sebab substrat merupakan habitat berpijah (spawning ground), mencari makan (feeding ground), dan habitat asuh (nursery ground). Uca spp. merupakan jenis kepiting yang hidup dalam lubang atau berendam dalam subtrat dan hanya ditemukan di hutan mangrove. Kepiting $U c a$ spp. akan selalu menggali lubang dan berdiam di dalam lubang untuk melindungi tubuhnya terhadap temperatur yang tinggi, karena air yang berada dalam lubang galian dapat membantu mengatur suhu tubuh melalui evaporasi (Bengen, 1999).

Arsana (2003) menyatakan ukuran butiran subtrat sangat menentukan sebaran kepiting karena kepiting telah menunjukkan adaptasi morfologis terhadap kondisi subtrat, serta berkaitan dengan lubang yang akan dibangunnya. Bengen (1999) juga menambahkan, di lumpur-lumpur lunak di dasar hutan mangrove yang tidak terlalu rimbun juga banyak ditemukan kepiting dari Genus Uca. Kepiting tersebut dapat dijumpai di daerah yang lebih dekat ke daratan, sehinggalebih menyesusaikan diri dengan lingkungan kering.

Menurut Bengen (2001), jenis substrat berkaitan dengan kandungan oksigen dan ketersediaan nutrien dalam sedimen. Pada substrat berpasir, kandungan oksigen relatif lebih besar dibandingkan dengan substrat yang halus, karena pada substrat berpasir terdapat pori udara yang memungkinkan terjadinya pencampuran yang lebih intensif dengan air di atasnya.
Suhu di lokasi pengamatan (perairan) berkisar antara $26^{\circ} \mathrm{C}$ hingga $30^{\circ} \mathrm{C}$. Hal ini dikarenakan pengamatan dilakukan pada pagi hingga siang hari (pukul 09.00-14.00 WIB) dan secara normal suhu di kawasan mangrove Kabupaten Purworejo masih tergolong normal untuk kehidupan kepiting biola dan mangrove. Menurut Kolehmainen et al. (1974), suhu yang baik untuk mangrove tidak kurang dari $20^{\circ} \mathrm{C}$. Menurut Saparinto (2010) secara umum kepiting hidup pada ekosistem mangrove, dapat bertahan pada suhu $23-32^{\circ} \mathrm{C}$.

Kepiting biola di kawasan mangrove Kabupaten Purworejo memiliki toleransi yang tinggi dan kisaran faktor lingkungan yang luas terhadap variasi yang terjadi di habitat setempat dengan nilai parameter keasaman $(\mathrm{pH})$ dapat dikatakan relatif seragam yang berkisar antara 6,0-8,0. Hal ini masih dianggap normal, karena menurut Gillikin et al. (2004) nilai $\mathrm{pH}$ yang normal bagi perairan payau adalah antara7,00-9,00. Untuk perairan estuari yang lebih ke arah darat, $\mathrm{pH}$-nya berkisar antara 7,50-7,90 sedangkan pada perairan yang lebih ke arah laut, $\mathrm{pH}$-nya akan cenderung seperti air laut yaitu 8,00-9,20.

Stasiun III memiliki $\mathrm{pH}$ air terendah karena lokasinya berada dekat dengan vegetasi daratan (area pertanian sawah) yang memiliki kandungan asam lebih tinggi dan jauh dari muara sungai, sehingga pengaruh air laut yang bersifat basa relatif kecil. pH air tertinggi di stasiun I karena lebih dekat dengan muara sungai sehingga sumber airnya lebih banyak berasal dari air laut. Sesuai dengan pendapat 
Effendi (2003), perairan yang lebih dominan dipengaruhi oleh air laut akan bersifat basa, karena derajat keasaman $(\mathrm{pH})$ air laut cendrung bersifat basa. Derajat keasaman $(\mathrm{pH})$ di perairan kawasan mangrove Kabupaten Purworejo, Jawa Tengah masih dalam batasan normal untuk kehidupan biota air laut termasuk kepiting biola.

Menurut Pratiwi (2010), bahwa $\mathrm{pH}$ yang $<5$ dan $>9$ akan menciptakan kondisi yang tidak menguntungkan bagi kehidupan makrozoobentos. $\mathrm{Hal}$ ini berarti stasiun penelitian berada pada $\mathrm{pH}$ yang baik untuk kehidupan $U_{c a}$ spp. Kondisi lingkungan penelitian sesuai dengan toleransi tumbuhan penyusun ekosistem mangrove, sehingga serasah yang dihasilkan dapat mencukupi kebutuhan hidup kepiting biola. Menurut Hardjowigeno (2007) bakteri berkembang dengan baik pada $\mathrm{pH}$ 5,5 atau lebih, sehingga pada lingkungan tersebut, penguraian serasah mangrove dapat berjalan dengan baik dan mendukung kehidupan kepiting biola.

Berdasarkan data pengamatan rata-rata salinitas yang diperoleh di daerah pengamatan adalah berkisar 3-9 ppt. Kisaran tersebut masih dalam kisaran oligohalin (0,5-5 ppt) sampai mesohalin (5-18 ppt) dan masih dapat mendukung kehidupan krustasea. Salinitas tertinggi berkisar 6-9 ppt terdapat di stasiun I (Desa Gedangan, daerah mangrove lebat dekat tambak). Hal ini disebabkan karena stasiun I berada lebih dekat dengan muara sungai sehingga air laut lebih banyak berpengaruh daripada air tawar dan tambak mengalami penguapan yang tinggi akibat tidak ada penutupan vegetasi. Sedangkan kisaran salinitas terendah sebesar 3-5 ppt terdapat stasiun III (Desa Ngentak, daerah mangrove jarang dekat dengan area pertanian berupa sawah). Hal ini karena lokasi tersebut berada lebih jauh dari daerah muara sehingga air laut kurang berpengaruh langsung. Sebaliknya air tawar lebih banyak berpengaruh karena kawasan mangrove di stasiun III lebih banyak menerima masukan air tawar dari saluran-saluran air sehingga terjadi pengenceran air yang mengakibatkan salinitasnya relatif lebih rendah daripada di stasiun I dan II. Selain itu, perairan mangrove di dekat sawah mengalami penguapan yang rendah akibat adanya penutupan vegetasi. Sejalan dengan pendapat Kulkarni et al. (2010) bahwa salinitas air sungai di kawasan mangrove berfluktuasi yang dipengaruhi oleh limpasan air tawar dari daratan dan masuknya air laut dari muara sungai.

Nilai rata-rata oksigen terlarut di kawasan mangrove Kabupaten Purworejo, Jawa Tengah berkisar antara 3,5-6,6 mg/L. Konsentrasi oksigen terendah terdapat di stasiun 3, sedangkan yang tertinggi berada di stasiun I, namun secara keseluruhan tidak berbeda nyata. Konsentrasi oksigen terlarut di perairan kawasan mangrove Kabupaten Purworejo, Jawa Tengah relatif baik untuk menunjang kehidupan kepiting biola.

\section{Vegetasi Mangrove di Lokasi Penelitian}

Vegetasi mangrove pada stasiun I adalah R.mucronata, Nypa fruticans, Sonneratia alba, dan Hibiscus tiliaceus. Vegetasi mangrove pada stasiun II adalah Sonneratia caseolaris, Rhizophora stylosa, N.fruticans, H.tiliaceus, dan Morinda citrifolia. Vegetasi mangrove pada stasiun III adalah S.alba, S.caseolaris, N.fruticans, dan R.mucronata (Tabel 3).

Tabel 3 Kerapatan vegetasi mangrove (individu/ha)

\begin{tabular}{cccccccccc}
\hline \multirow{2}{*}{ Jenis } & \multicolumn{3}{c}{ Stasiun 1 } & \multicolumn{3}{c}{ Stasiun 2 } & \multicolumn{3}{c}{ Stasiun 3 } \\
\cline { 2 - 9 } & Pohon & Pancang & Semai & Pohon & Pancang & Semai & Pohon & Pancang & Semai \\
\hline R.mucronata & 400 & 7260 & 71125 & - & - & - & - & 40 & - \\
N.fruticans & 20 & 40 & 500 & 185 & 60 & 500 & 25 & 140 & 250 \\
H.tiliaceus & 5 & 160 & 125 & - & 100 & - & - & - & - \\
S.alba & 15 & - & - & - & - & - & 190 & 340 & 15125 \\
S.caseolaris & - & - & - & 210 & 1380 & 21500 & 105 & 640 & 6375 \\
R.tylosa & - & - & - & 15 & 860 & 8500 & - & - & - \\
M.citrifolia & - & - & - & - & 20 & - & - & - & - \\
\hline
\end{tabular}

Terdapat keterkaitan antara vegetasi mangrove dengan kepiting biola di kawasan mangrove
Kabupaten Purworejo, Jawa Tengah. Jenis vegetasi mangrove yang banyak terdapat di stasiun I adalah 
R.mucronata baik pada fase pohon, pancang, dan semai. Kondisi ini sangat mendukung kehidupan kepiting biola karena kepiting biola dapat berlindung, tumbuh, berkembang, dan mencari makan di antara akar-akar R.mucronata. Oleh karena itu, kelimpahan jenis (kepadatan) kepiting biola tertinggi terdapat di stasiun 1 .

\section{Kesimpulan Dan Saran}

\section{Kesimpulan}

Dari penelitian didapatkan 7 jenis kepiting biola, yaitu Uca annulipes, U.crassipes, U.paradussumieri, U.rosea, U.tetragonon, U.vocans, dan U.vomeris. Indeks keanekaragaman kepiting biola di kawasan mangrove Kabupaten Purworejo, Jawa Tengah pada stasiun $1(1,67)$ dan stasiun 2 (1,90) tergolong sedang. Adapun indeks keanekaragaman kepiting biola di stasiun $3(0,64)$ tergolong rendah. Kondisi lingkungan di seluruh stasiun relatif baik untuk kehidupan mangrove dan kepiting biola, yaitu suhu $26-30^{\circ} \mathrm{C}, \mathrm{pH}$ 6-8, oksigen terlarut 3,5-6,6 mg/L, salinitas 3-9 ppt, dan substrat lumpur berpasir. Kerapatan vegetasi mangrove berkaitan dengan kelimpahan jenis (kepadatan) kepiting biola.

\section{Saran}

Perlu adanya pengelolaan dan pelestarian kawasan mangrove yang lebih baik melibatkan peran aktif masyarakat setempat dan dukungan dari pemerintah serta kalangan akademisi melalui berbagai upaya rehabilitasi dan pengembangan ekosistem mangrove di Kabupaten Purworejo sesuai karakteristik setempat (special site) demi terwujudnya pembangunan yang berkelanjutan (sustainable development).

\section{Daftar Rujukan}

Arsana, I N. 2003. Komunitas Kepiting (Brachyura: Ocypodidae dan Sesarmidae) di Teluk Lembar, Lombok Barat. Tesis. Yogyakarta: Program Pascasarjana Universitas Gadjah Mada.

Badan Perencanaan Pembangunan Daerah Kabupaten Purworejo. 2016. Potensi Unggulan Daerah. Purworejo: Badan Perencanaan Pembangunan Daerah Kabupaten Purworejo.

Bengen, D.G. 1999. Pedoman Teknis Pengenalan dan Pengelolaan Ekosistem Mangrove. Bogor: Pusat Kajian Sumber Daya Pesisir dan Lautan, Institut Pertanian Bogor.

.2001. Ekosistem dan Sumber Daya Pesisir dan Laut serta Pengelolaan secara Terpadu dan Berkelanjutan. Prosiding Pelatihan Pengelolaan Wilayah Pesisir Terpadu 29 Oktober-3 November 2001. Bogor.

Crane, J. 1975. Fiddler Crabs of the Word Ocypodidae: Genus Uca. New Jersey: Princetown University Press.

Hamidah, A., Fratiwi, M., dan J. Siburian. 2014. Kepadatan Kepiting Biola (Uca spp) Jantan dan Betina di Desa Tungkal 1 Tanjung Jabung Barat. Jurnal Penelitian Universitas Jambi Seri Sains 16 (2): $43-50$.

Hardjowigeno, S. 2007. Ilmu Tanah. Jakarta: Akademika Pressindo.

Kolehmainen, S., T. Morgan, and R. Castro. 1974. Mangrove Root Communities in A Thermally altered area in Guayanilla Bay. In Gibbons, J.W., and R.R. Sharitz (Eds) Thermal Ecology.U.S: Atomic Energy Commission.

Kulkarni, V.A., T.G. Jagta, N.M. Mhalsekar, and A.N. Naik. 2010. Biological and Environmental Characteristics of Mangrove Habitats from Manori Creek, West Coast, India. Environ Monit Assess. 168:587-596.

Murniati, D.C. 2009. Perbandingan Luas Tutupan Spoon Toped Setae Maksiliped Kedua pada Uca spp, (Brachyura: Ocypodidae). Zoo Indonesia, 18 (1): 1-8.

Murniati, D.C. 2010. Keanekaragaman Uca spp dari Segara-Anakan, Cilacap, Jawa Tengah sebagai 
Pemakan Deposit. Fauna Indonesia, 9 (1): 19-23.

Ng, Peter K.L. and N. Sivasothi.2001. A Guide to Mangroves of Singapore. Singapore: Singapore Science Center.

Noor, Y.R., Khazali M., dan I.N.N Suryadiputra. 2012. Panduan Pengenalan Mangrove di Indonesia. Bogor: Wetlands International Indonesia Programme.

Odum, E.P. 1993. Dasar-Dasar Ekologi. Yogyakarta: Gadjah Mada University Press.

Onrizal.2008. Panduan Pengenalan dan Analisis Vegetasi Hutan Mangrove. Medan: Universitas Sumatera Utara.

Pemerintah Kabupaten Purworejo. 2011. Peraturan Daerah Kabupaten Purworejo Nomor.27 Tahun 2011 Tentang Rencana Tata Ruang Wilayah Kabupaten Purworejo Tahun 2011-2031. Purworejo: Pemerintah Daerah Kabupaten Purworejo.

Polidoro, B.A., Carpenter, K.E., Collins, L., Duke, N.C., Ellison, A.M., Ellison, E.J., Farnsworth, Fernando, E.S., Kathiresan, K., Nico, E., Koedam,Livingstone, S.R., Miyagi, T., Moore, G.E., Nam, V.N., Ong, J.E., Primavera, J.H., Salmo, S.G., Sanciangco, J.C, Sukardjo, S., Wang, Y., and J.W.H. Yong. 2010. The Loss of Species: Mangrove Extinction Risk and Geographic Areas of Global Concern. PLoS ONE April 2010 (5): 1-10.

Pratiwi, R. 2010. Asosiasi Krustasea di Ekosistem Padang Lamun Perairan Teluk Lampung. Ilmu Kelautan, 15 (2): 66-76.

Rosenberg, M. 2001. Filddler Crab Claw Shape Variation: a Geometric Morphometric Analysis Across the Genus Uca (Crustacea: Brachyura: Ocypodidae). Biological Jurnal of the Linean Society, 75 (13): 147-162.

Saparinto C. 2010. Usaha Ikan Konsumsi di Lahan $100 \mathrm{~m}^{2}$. Jakarta: Penebar Swadaya.

Soegianto, A. 1994. Ekologi Kuantitatif: Metode Analisis Populasi dan Komunitas. Jakarta: Usaha Nasional.

Suprayogi, D., Siburian, J., dan A. Hamidah. 2014. Keanekaragaman kepiting biola (Uca spp) di Desa Tungkal 1 Tanjung Jabung Barat. Biospecies 7 (1): 22-28.

Wilsey, B. J. 2000. Biodiversity and Ecosystem Functioning Importance of Species Evennes in an Old Field. Ecology, 81: 887-892.

Wulandari,T. Hamidah A. dan Sirbulan J. 2013. Morfologi Kepiting Biola (Uca spp) di Desa Tungkal 1 Tanjung Jabung Barat Jambi. Biospecies, 6 (1): 6-14.

Yulianto, A. 2006. Keanekaragaman Kepiting di Hutan Mangrove Desa Tungkal, Tanjung Jabung Barat, Jambi. Bogor: Institut Pertanian Bogor. 